\title{
河川遡上期のウキゴリ類の遊泳能力に関する 基礎実験 \\ SWIMMING CHARACTERISTICS OF GOBY DURING THE UPSTREAM RIVER MIGRATION PERIOD
}

\author{
矢田谷健一 1 - 泉 完 $^{2} \cdot$ 東 $\quad$ 信行 $3 \cdot$ 丸居 篤 4 \\ Kenichi YATAYA, Mattashi IZUMI, Nobuyuki AZUMA and Atsushi MARUI \\ 1正会員 農修 株式会社建設技術研究所 東北支社（广980-0014 仙台市青葉区本町2-15-1） \\ 2正会員 農博 弘前大学・教授 農学生命科学部 地域環境工学科（T036-8561 弘前市文京町3） \\ 3 正会員 農博 弘前大学・准教授 農学生命科学部 生物学科（T036-8561 弘前市文京町3） \\ 4農博 弘前大学・准教授 農学生命科学部 地域環境工学科（干036-8561 弘前市文京町3）
}

\begin{abstract}
In order to understand the swimming characteristics and swimming ability of demersal fish, swimming experiments were conducted using Goby (Gymnogobius urotaenia sp.) during the upstream river migration period. Our observations were as follows: 1) at a flow velocity of $17 \mathrm{~cm} / \mathrm{s}$ and higher, Gobies adhered to the bottom using the suction cups on their ventral fins, and showed repeated advancement and adherence; 2) the body length of Gobies is between $3-4 \mathrm{~cm}$, and their average swimming speed was found to be $56-107 \mathrm{~cm} / \mathrm{s}$, which is $16-31$ times the body length; 3) a swimming-curve-formula defining the relationship between swimming speed and swimming time was obtained; and 4) at flow velocities of $44 \mathrm{~cm} / \mathrm{s}$ and $53 \mathrm{~cm} / \mathrm{s}$, we frequently observed Gobies flowing down in exhaustion during advancement.
\end{abstract}

Key Words : Goby (Gymnogobius urotaenia), Swimming ability, Swimming speed, Swimming distance, fishway

\section{1.はじめに}

河川に取水堰や頭首工などの河川横断構造物が設けら れると，魚類等の河川内移動が阻害され，生息場所の分 断や流程分布の制約が生じる ${ }^{1), 2)}$. このため, 日本各地 の河川では，アユや遡河性サケ科魚類などの漁業対象魚 種の遡上を目的とした魚道設計が進められてきた ${ }^{3)}$. し かしながら，サケ科魚類の遡上を目的としたプールタイ プ魚道において, 通し回遊性のカジカ属魚類やウキゴリ 属魚類が全く利用できていない事例が報告されており ${ }^{4)}$, 多様な魚種の河川移動に対応した魚道の設計が求められ ている.

このような中で，国土交通省は，2005年に「魚がのぼ りや寸い川づくりの手引き（以下，手引きと称す）」5) を公表し，魚道設計にあたり，魚道内の最大流速は，対 象魚と寸る魚種のうち最も遊泳能力の弱い魚の突進速度 以下とすることを基本とした．同様に，「頭首工の魚道 設計指針」の)では，魚道設計流速は，魚道上り口付近〜 魚道内〜魚道下り口付近において想定される遡上経路の
全線にわたって，設計対象魚種の中で最も遊泳能力が低 い魚種の突進速度以下とすることを謳っている。こうし た社会的ニーズと基準類の整備を受け，近年では，緩勾 配バイパス式魚道や側壁に傾斜をつけた魚道等，遊泳能 力が弱い魚類や甲殼類に配慮した魚道の開発，整備，評 価も進められている7,8),9). しかし, 緩勾配タイプの魚道 は，その構造上，必要スペースとコストが従来からの魚 道に比べて大きくなるため, 対象箇所の制約によっては 採用できないことも考えられる.

また，手引きでは，魚道の設計流速設定に必要となる 魚類の遊泳能力に関する知見が現状では乏しいため, 水 路実験等による新しい知見の集積の必要性も課題として 挙げている.ここで, 魚類の遊泳能力に関する研究をレ ビューすると， Blaxter $\left.{ }^{10}\right)$ は，1〜5秒間遊泳できる最大遊 泳速度を突進速度と定義し，その速度は標準体長（以下， 体長と称す）の10倍程度が一般的な目安とされている. また，日本に生息寸る淡水魚類の遊泳能力に関寸る研究 としては，例えば，塚本・梶原 ${ }^{11)}$ や梨本 ${ }^{12)}$ などの実験研 究があり, 近年では, ウグイやオイカワ, アユ, カワム ツ，キンブナの突進速度が体長の10倍を大きく上回るこ 
とが実験によって明らかにされている13), 14), 15),16). しかし ながら，遊泳能力が弱いとされる八ゼ科・カジカ科など の底生魚 ${ }^{4}$ の遊泳能力に関寸る科学的見地に基づいた知 見は，シロウオの実験研究 ${ }^{177}$ を除いてほとんどなく，底 生魚を対象とした魚道の設計流速を定めるためには，模 型を使った遡上実験 18, , 19), 20)を実施する他は, 既往の近似 事例を参考にするか技術者の経験に頼らざるを得ないの が現状である。

以上のことから，本研究では，魚道設計に資する底生 魚の遊泳特性および游泳能力に関する知見を得ることを 目的とし, 遊泳能力の弱い底生魚の代表として, 河川遡 上期の小型のウキゴリ類を対象とした遊泳実験を行った.

\section{2. 実験方法}

\section{（1）供試魚}

供試魚には，青森県一級河川岩木川河口から $11 \mathrm{~km}$ 地 点に位置する芦野頭首工直下流で採捕されたウキゴリ類 を用いた．同水系では，ウキゴリ Gymnogobius urotaenia の他に, 確認個体数はわずかであるがスミウキゴリ Gymnogobius petschiliensisが確認されており，シマウキゴ リ Gymnogobius opperiensについては確認の記録がない21). 本実験に供試した個体は体サイズが小さく, 厳密な同定 が困難であったことから，ウキゴリとスミウキゴリを区 別せずにウキゴリ類と称して供試した.

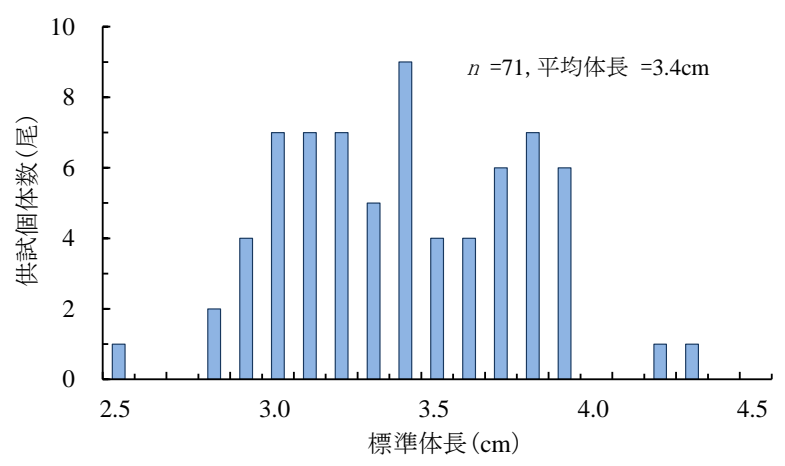

図-1 供試魚の体長分布
ここで，ウキゴリの生活史について整理すると，川の 産卵場で㨼化した仔魚は一度海に入り，そこで2〜3ケ月 間滞留して全長 $2.0 \mathrm{~cm}$ となり, 再び川に戻って遡上し, 下流から中流までのそれぞれの棲息場に棲みつくと考え られている22．実験地点である岩木川下流域では，毎年 概ね6月～8月にかけてウキゴリ類の活発な遡上が見られ， 実験には河川を遡上してきた当歳魚を用いるものとした. 本実験で供試したウキゴリの個体数は71尾である.また, 供試魚の体長分布は図-1に示寸とおり $3 \mathrm{~cm}$ 台が主であり, 平均体長は $3.4 \mathrm{~cm}$ である。 なお，実験に際して供試魚の 利用は一度きりとし，再利用は行わなかった。

\section{（2）実験場所と実験日および実験装置}

本研究では, 泉ら ${ }^{177}$ の実験のようなスタミナトンネル （管水路）を用い，供試魚を採捕した河川の水を直接通 水させて使用する野外実験を採用した．実験場所は，供 試魚を採捕した地点の上流側に位置する芦野頭首工左岸 である. 実験日は，2014年6月28～30日と7月19～20日の 計5日間で，集中的に実施した（表-1）.

実験装置の概要を図-2に示寸，実験装置は，余水吐と 整流板を付設したマノメーター付の貯水槽（幅 $35 \mathrm{~cm}$ ・ 高さ $30 \mathrm{~cm}$ ・長さ $55 \mathrm{~cm} ）$ ，スタミナトンネル，挿入用傾 斜型スタンドパイプ, フレキシブルホース，流速調節用 コック 2 連で構成されている. 貯水槽とスタミナトンネ ルは架台の上に水平に設置され，スタミナトンネルの脇 には目盛付の白色板がある. スタミナトンネルは透明ア

\section{表-1＼cjkstart実験日と実験条件}

\begin{tabular}{|c|c|c|c|c|c|c|c|}
\hline \multirow[b]{2}{*}{ 実験月日 } & \multirow[b]{2}{*}{$\begin{array}{l}\text { 実験 } \\
\text { 番号 }\end{array}$} & \multirow[b]{2}{*}{ 天 } & \multirow{2}{*}{$\begin{array}{l}\text { 水温 } \\
\left({ }^{\circ} \mathrm{C}\right) \\
\end{array}$} & \multicolumn{4}{|c|}{ 供試魚（尾） } \\
\hline & & & & $\begin{array}{c}2 \mathrm{~cm} \\
\text { 台 }\end{array}$ & $\begin{array}{c}3 \mathrm{~cm} \\
\text { 台 }\end{array}$ & $\begin{array}{c}4 \mathrm{~cm} \\
\text { 台 }\end{array}$ & 計 \\
\hline $2014 / 6 / 28$ & Run.1 & 晴れ & 24.6 & 2 & 8 & 0 & 10 \\
\hline $2014 / 6 / 29$ & Run.2 & 曇り & 24.3 & 0 & 9 & 1 & 10 \\
\hline $2014 / 6 / 30$ & Run.3 & 曇のち晴 & 25.5 & 2 & 14 & 0 & 16 \\
\hline $2014 / 7 / 19$ & Run.4 & 晴れ & 23.4 & 0 & 5 & 0 & 5 \\
\hline $2014 / 7 / 20$ & Run.5 & 晴れ & 23.5 & 3 & 26 & 1 & 30 \\
\hline & & 計 & & 7 & 62 & 2 & 71 \\
\hline
\end{tabular}

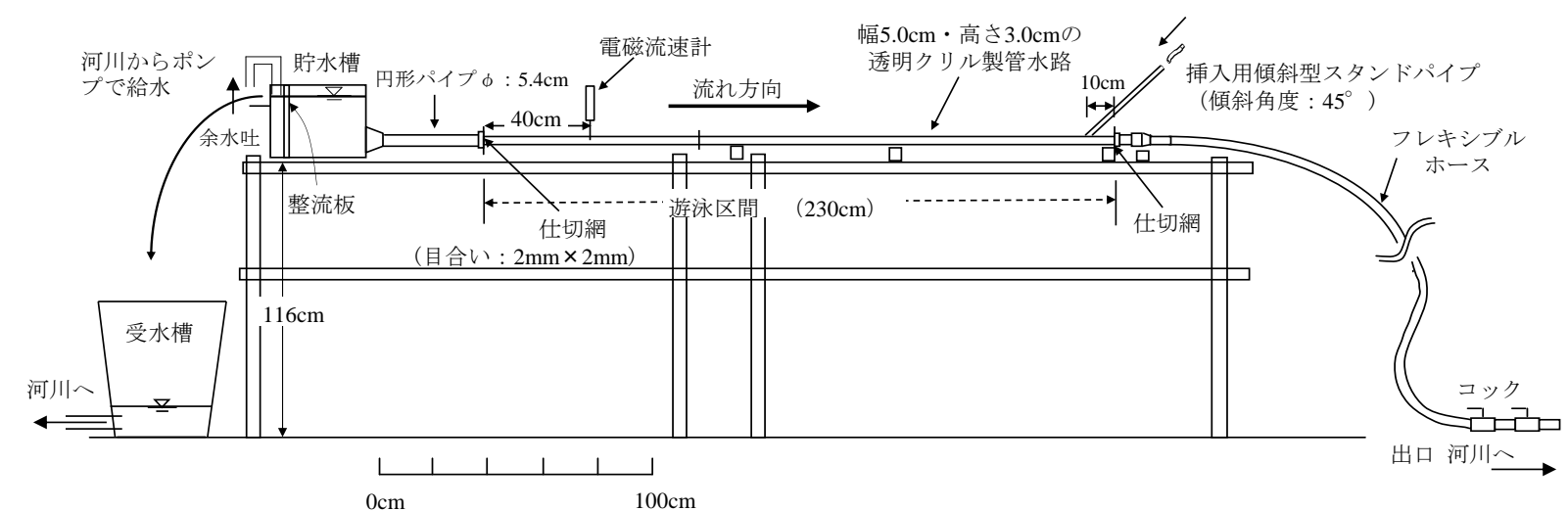

図-2＼cjkstart実験装置の概要 
クリル製長方形パイプで，その内寸は，幅 $5.0 \mathrm{~cm}$ ，高さ $3.0 \mathrm{~cm}$ ，長さ $230 \mathrm{~cm}$ である，パイプ断面の高さと幅の寸 法はウキゴリの遊泳に支障がない大きさである23, 24)。ま た，スタミナトンネル上端部から下流側 $40 \mathrm{~cm} の$ 地点に 二軸電磁流速計（ACM-250；アレック電子，測定精度 $\pm 2 \%$ ，センサー部 $\phi 5 \mathrm{~mm} ）$ が据付けられ，スタミナト ンネルの断面中心部の流速がリアルタイムに計測できる ようになっている.

スタンドパイプから挿入された供試魚は，スタミナト ンネル上端部に設けられた仕切網まで遊泳できるように なっており，力尽きて流された個体は，スタミナトンネ ル下端部の仕切網位置から採捕できる.

\section{（3）スタミナトンネル内のウキゴリ類の遊泳行動}

本実験に先立って予備実験を行い，スタミナトンネル 内におけるウキゴリ類の遊泳行動の観察を行った. スタ ミナトンネル内の流速を概ね2 20 ～30 cm/s とした状態で個 体を挿入すると, ウキゴリ類は腹鯺の吸盤を用いてスタ ミナトンネル底面に吸着した. その後, 尾鱪を振動させ て上流側に向かって突進行動（以降, 前進と称す）を起 こし, 再び底面に吸着し, 以降, 前進と吸着を繰り返し た（図-3）。但し，挿入後に吸着した状態のまま一向に 前進しない個体もいた。 これらの個体については, 徐々 にスタミナトンネル内の流速を上げていくと，促される ように前進することが確認された。 宮園・戸松 ${ }^{19)}$ は, 粗石付斜路式魚道の模型実験において，ウキゴリ類と同 じハゼ科のカワヨシノボリの遡上行動を観察し, カワヨ シノボリが吸盤で水路底に張りつきながら流れに抵抗し， 胸鯺で水路底を押しつけるように移動していくことを報 告している. 一方, 本研究では, 予備実験から本実験を 通して，供試したウキゴリ類のうち胸鰭を用いて前進し た個体は確認されず，前進時にはすべて尾鯺を振動させ る遊泳形態をとった.

\section{（4）実験項目と実験方法}

予備実験時のウキゴリ類の遊泳行動を踏まえ, スタミ ナトンネル内の初期流速は概ね $20 \mathrm{~cm} / \mathrm{s} \sim 30 \mathrm{~cm} / \mathrm{s}$ とし, 底 面に吸着するごとに流速を増大させるものとした（図一 3）。この際の設定流速值は, 全供試一律とし, 電磁流 速計の読み值で $20 \mathrm{~cm} / \mathrm{s}, 30 \mathrm{~cm} / \mathrm{s}, 40 \mathrm{~cm} / \mathrm{s}, 50 \mathrm{~cm} / \mathrm{s}$, $60 \mathrm{~cm} / \mathrm{s}, 70 \mathrm{~cm} / \mathrm{s}, 80 \mathrm{~cm} / \mathrm{s}, 90 \mathrm{~cm} / \mathrm{s}$ の $8 \mathbf{E}$ 階とした. 但し, 1段階分流速を上げても吸着しつづける個体もあり，こ の場合は吸着した状態のまま流速を段階的に増大させる ものとした. そして, 前進行動を起こした際の吸着地点 から前進後の吸着地点までを1ステップと位置づけ, そ の間の遊泳時間と遊泳距離を計測した。なお，流速が定 常状態になる前に前進をはじめる個体があり，この場合 は, 二軸電磁流速計によって流速が定常状態となった時 点を確認し, その時点・地点から遊泳時間と遊泳距離の 計測を開始した．さらに，供試魚が力尽きて下流方向に
流された際の流速を記録した.

実験時のスタミナトンネル内の流れは満流状態とし， 出口部のコックによって流速を調節した。.また, 供試魚 の遊泳時間・遊泳距離の測定および流況把握のために, スタミナトンネル上方にデジタルビデオカメラ（SONY 製：HDR-CX420）を設置して，供試魚の遊泳行動と二 軸電磁流速計のモニターを同時撮影した.

供試魚の体長・体高・体幅は，遊泳の際のストレスを 考慮して遊泳後に計測した．また，あらかじめ実験装置 出口部において，設定流速值ごとに流量観測を行い，二 軸電磁流速計の読み值と断面平均流速の関係を調べた.

\section{（5）遊泳速度の整理方法}

本実験では，遊泳距離を遊泳時間で除して求めた対地 速度に後述寸る管内代表流速を加えた值を遊泳速度とし

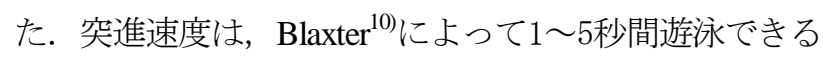
最大遊泳速度と定義されているが，本実験では，遊泳時 間が1秒に満たない前進行動も多く確認されたことから， 突進速度ではなく単に遊泳速度と称して整理するものと した.

なお，泉ら ${ }^{25)}$, 26) はプールタイプ魚道を遡上する魚が， 1秒に満たない短い時間で隔壁部を通過する事例を報告 しており，魚が魚道を遡上できるかどうか判断する上で は，本実験の整理方法も参考になると考えられる.

\section{3. 実験結果と考察}

\section{（1）水温と管内水理特性 ·管内代表流速}

実験時の天気は晴れまたは曇りで，河川水温は23.4〜 $25.5^{\circ} \mathrm{C}$ である（表-1）。

本実験で用いた管内の流速分布は，泉ら ${ }^{17)}$ によって 計測されており, 壁面の摩擦抵抗のため下層側と上層側 の流速が中層部に比べて遅くなっている．ウキゴリ類は おもに底から $1 \mathrm{~cm}$ 以下の底面近傍を遊泳したことから， 遊泳速度算定に用いる管内代表流速は, 魚の頭部近傍の 流速とするために，実測流量を管路断面積で除した断面 平均流速に，泉ら ${ }^{17)}$ によって得られている鉛直方向流 速分布による底面から約 $5 \mathrm{~mm}$ 地点の補正率を乗じて求め た（表-2）.

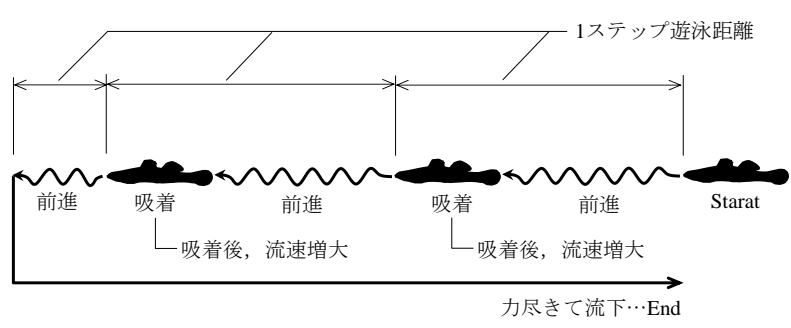

図-3＼cjkstart供試魚の遊泳行動と流速操作の模式図 
表-2スタミナトンネル内の設定流速値

\begin{tabular}{ccccccccc}
\hline 設定流速值 No. & No1 & No2 & No3 & No4 & No5 & No6 & No7 & No8 \\
\hline 電磁流速計読み值 $(\mathrm{cm} / \mathrm{s})$ & 20 & 30 & 40 & 50 & 60 & 70 & 80 & 90 \\
断面平均流速 $(\mathrm{cm} / \mathrm{s})$ & 19 & 29 & 38 & 48 & 58 & 68 & 78 & 87 \\
管内代表流速 $(\mathrm{cm} / \mathrm{s})$ & 17 & 26 & 35 & 44 & 53 & 62 & 71 & 80
\end{tabular}

\section{（2）体長と遊泳速度の関係}

図-4は，供試魚すべてを対象に体長と遊泳速度の関係 を整理したものである．魚類の体サイズと遊泳速度との 間には正の相関があるとされているが10), 11)，本実験で供 試した個体の体長分布の範囲では，いずれの流速条件で も体長と遊泳速度との間に明確な関係はみられなかった。 この要因として，本実験の供試魚の体長分布の幅が $2 \mathrm{~cm}$ 未満（標準偏差 $0.4 \mathrm{~cm} ）$ と小さいことが考えられ，体長 と遊泳速度の関係を明らかにするためには，より体サイ ズの大きい個体を使った実験值の集積が必要と考えられ る.

\section{（3）遊泳特性}

以降では, 計測数が多く得られた体長 $3 \mathrm{~cm}$ 台の供試魚 について結果を整理する。

図-5，図-6，図-7は，設定流速別に1ステップの遊泳 速度と遊泳時間, 遊泳距離の平均值および標準偏差を整 理したものである. 図-5より，1ステップの平均遊泳速 度は56〜107 cm/sで，体長の16〜31倍に相当寸る.また， 流速が増加するとともに遊泳速度が大きくなる傾向が認 められ，このように流れ場に応じて遊泳速度を変化させ る特徴は, ウグイ ${ }^{13)}$ やオイカワ ${ }^{14,}{ }^{15)}$ と一致する. 一方, 1ステップの平均遊泳時間は0.6〜2.9秒で，流速が増加寸 るとともに，遊泳時間は短くなった（図-6）。同様に, 1ステップの遊泳距離も流速が増加寸るとともに短くな る傾向が認められ（図-7），供試魚は流速条件に応じ, 吸盤を利用して1ステップの遊泳時間・遊泳距離を巧み に調整しているものと考えられる.

\section{（4）遊泳速度と遊泳時間の関係}

図-8は，1ステップの遊泳時間と遊泳速度の関係を示 したものである．個体によるばらつきがみられるものの， 遊泳速度が増加するとともに遊泳時間が指数曲線的に短 くなる傾向が認められる。塚本・梶原 ${ }^{11}$ は，こうした魚 類の遊泳速度と遊泳時間の関係を(1)式によって整理して いる.

$$
V t^{k}=a
$$

ここで, $V$ : 遊泳速度 $(\mathrm{cm} / \mathrm{s}), t$ : 遊泳時間 $(\mathrm{s})$, $a$ : 一秒間持続できる遊泳速度の理論值, $k$ : 定数 $(0<k$ <1）である．そこで体長 $3 \mathrm{~cm}$ 台の計測数 $n=145$ について, (1)式の $a$ 值および $k$ 值を最小自乗法によって求めた. その 結果, $a=80, k=0.19$ となった.

\section{（5）供試魚流下時の流速}

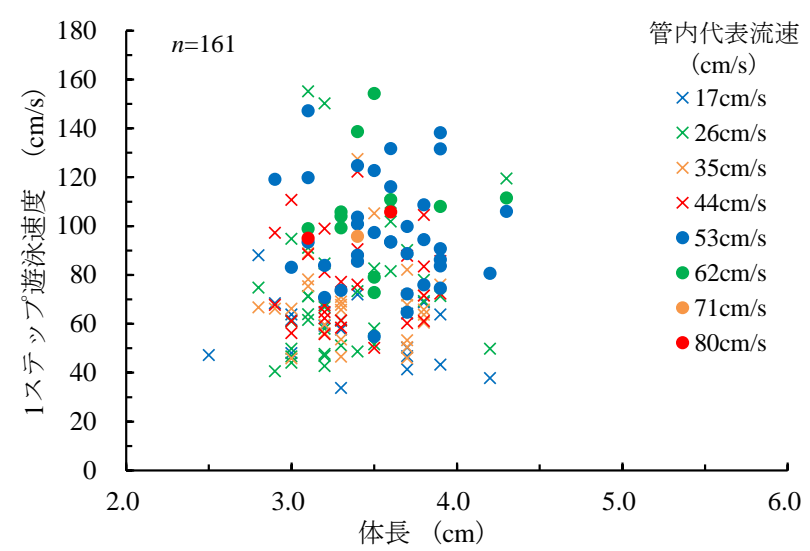

図-4 体長と遊泳速度の関係

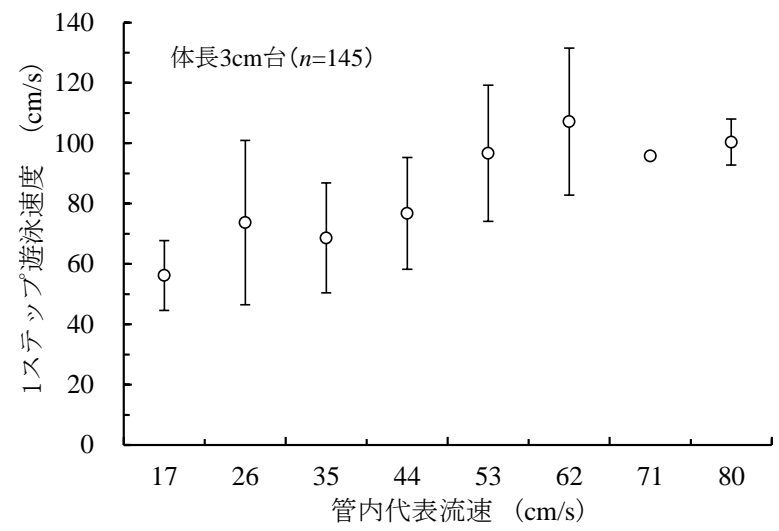

図-5 管内代表流速と遊泳速度の関係

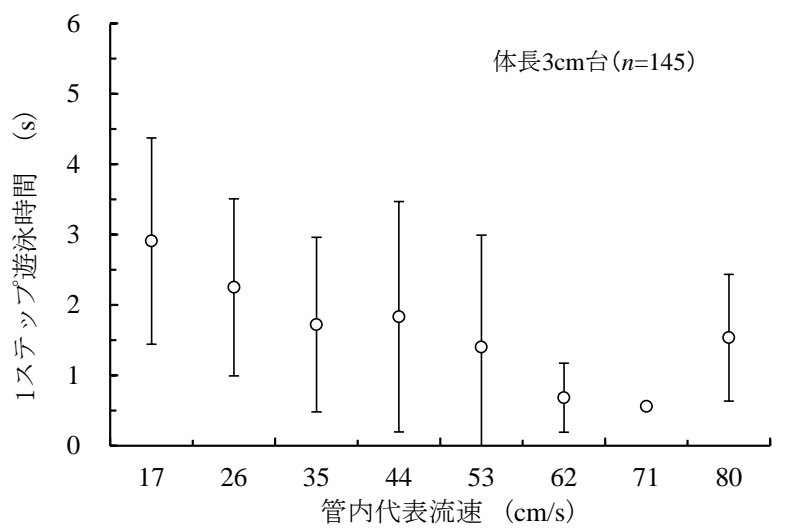

図-6 管内代表流速と遊泳時間の関係

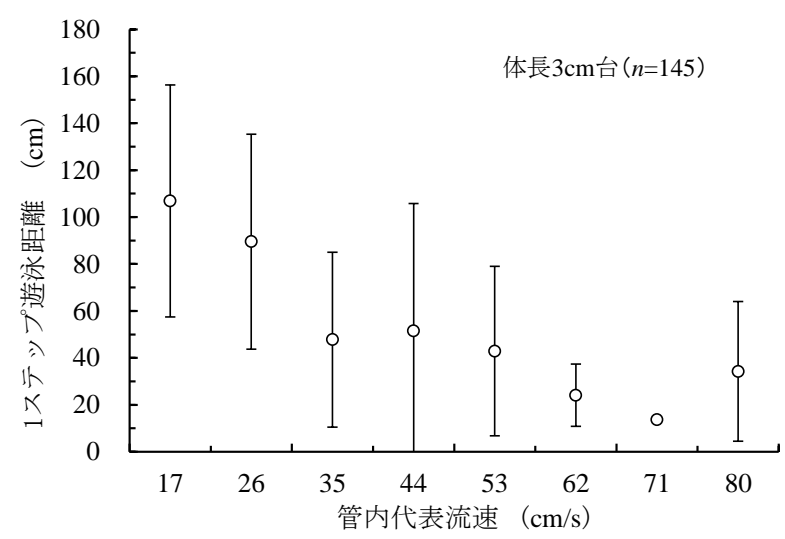

図-7 管内代表流速と遊泳距離の関係 
図-9は，供試魚が力尽きて下流方向に流された際の管 内代表流速を整理し，各設定流速における流下個体数の ヒストグラムと累積相対度数をまとめたものである。な お，吸盤によって吸着した状態から流下した個体や前進 中に頭を反転させて流下した個体は除いている。流速 $35 \mathrm{~cm} / \mathrm{s}$ 以下の条件で流下した個体は $10 \%$ と少なかったが, 流速 $44 \mathrm{~cm} / \mathrm{s}, 53 \mathrm{~cm} / \mathrm{s}$ の条件で, 前進中に力尽きて流下す る個体が顕著に多く，流速 $53 \mathrm{~cm} / \mathrm{s}$ までに流下した個体の 割合は，78\%に上った。

魚道の流速設定や遡上経路の距離設定について言及す るためには，一定流速条件において流速とウキゴリが前 進できる総距離の関係を把握する必要があり，本実験で はこれらの解明には至っていないが，体長 $3 \mathrm{~cm}$ 台のウキ ゴリ類は，魚の頭部近傍の流速が概ね $240 〜 50 \mathrm{~cm} / \mathrm{s}$ 超え ると吸盤を使って前進と吸着を繰り返すことが困難にな るものと考えられる. 泉ら 25), 27)は，実際のコンクリート 製プールタイプ魚道においてヨシノボリ類・ウキゴリ類 と考えられる底生魚が吸盤を使いながら隔壁部を遡上し

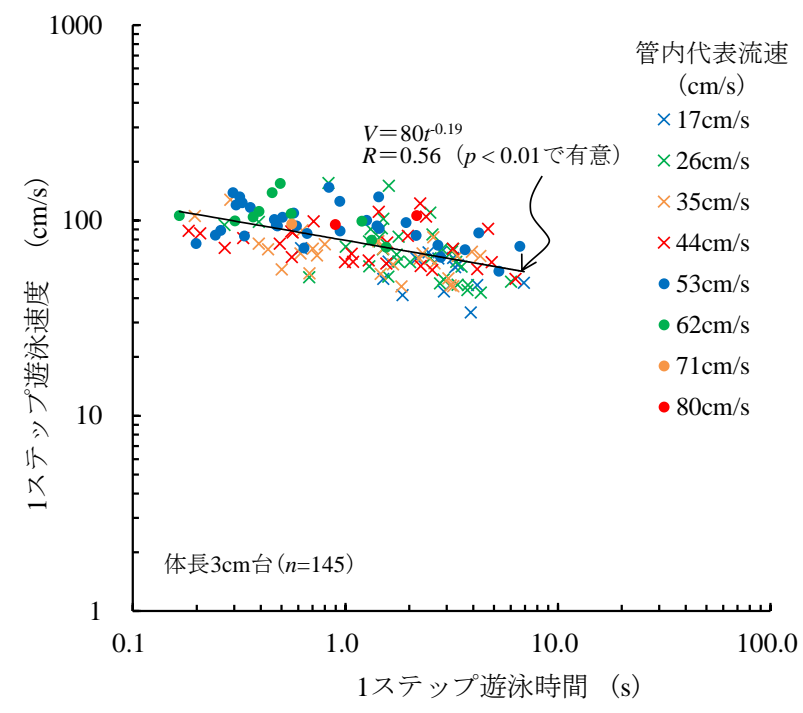

図-8＼cjkstart遊泳時間と遊泳速度の関係

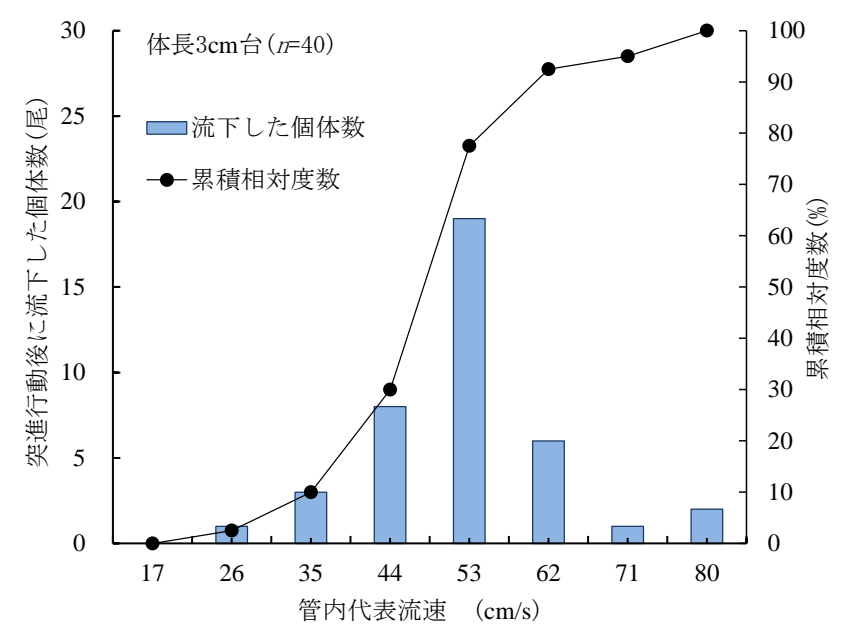

図-9＼cjkstart管内代表流速と流下個体数の関係
ていくことを報告している．また，底生魚の事例ではな いものの，現地魚道隔壁での遊泳速度に関する調査研究 事例 ${ }^{25}$ では，平均体長 $8.7 \mathrm{~cm}$ のアユ・ウグイが，距離約 $20 \mathrm{~cm}$ の越流部を $190 \mathrm{~cm} / \mathrm{s} \sim 250 \mathrm{~cm} / \mathrm{s}$ の遊泳速度で通過した ことを報告しており，その速度がスタミナトンネル内で 計測された遊泳速度 ${ }^{13)}$ と概ね一致することがわかってい る.このことから，スタミナトンネルによる実験から得 られたウキゴリ類に関する本知見も，魚道設計に際して 一つの参考值になると考えられる．ただし，底面の材 質・状態によってウキゴリ類の吸着能力には差異が生じ ることも考えられ，この点は今後の課題である.

\section{4. まとめと今後の課題}

魚道設計に資する底生魚の遊泳特性および遊泳能力に 関する知見を得ることを目的に，河川遡上期の小型のウ キゴリ類を対象とした遊泳実験を行った。 本研究で得ら れた知見を以下に示す.

(1) ウキゴリ類は腹鯺の吸盤を用いて底面に吸着し, $17 \mathrm{~cm} / \mathrm{s}$ 以上の流れ場において，前進と吸着を繰り 返した。

(2) 体長 $3 \mathrm{~cm}$ 台のウキゴリ類の平均遊泳速度は 56〜 $107 \mathrm{~cm} / \mathrm{s}$ で，その速度は体長の16～31倍に相当した。 また，流速が増加するとともに遊泳速度が大きく なる傾向が認められた.

(3) 体長 $3 \mathrm{~cm}$ 台のウキゴリ類は，遊泳速度が増加すると ともに1ステップの遊泳時間が指数関数的に短くな る傾向が認められ，遊泳速度と遊泳時間の関係を 表す実験式を得た。

(4) 体長 $3 \mathrm{~cm}$ 台のウキゴリ類のうち，流速 $44 \mathrm{~cm} / \mathrm{s}$, $53 \mathrm{~cm} / \mathrm{s}$ の条件で，前進中に力尽きて流下する個体 が顕著に多く，この流れ場では，吸盤を使って前 進と吸着を繰り返すことが困難であったと考えら れた。

今後の課題としては，一定流速条件において， ウキゴ リ類が前進できる総距離を明らかにするとともに，ウキ ゴリ類以外の底生魚の遊泳特性・遊泳能力を解明する必 要がある.

また，本実験に用いたスタミナトンネルはアクリル製 であり，一般的な魚道に用いられるコンクリートや自然 石とは表面粗度が異なる. 加えて, 魚道は開水路流れで あり，気泡を含んだ複雑な流れ場であることが多い。こ

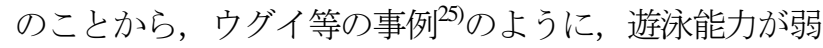
い底生魚についても，実際の魚道における遡上行動と水 理特性の関係を調べ，スタミナトンネル内での遊泳能力 と魚道内での遊泳能力とを比較検証するような実証的研 究の集積が必要である. 
謝辞 : 本実験を行うにあたり, 岩木川漁業協同組合の齋 藤氏にはウキゴリ類の提供で種々お世話いただいた。 ま た, 各関係機関, 弘前大学農学生命科学部農業水利学研 究室の院生・学生諸氏から多大な協力と援助をいただい た．ここに記して心より感謝の意を表します．また，本 研究の一部は，平成26年度文科省科学研究補助金基盤研 究(C), 平成26年度河川整備基金を受けている.

\section{参考文献}

1）棶田孝晴，瀬谷政貴 : 利根川最下流域に流入する感潮河川 最下流部の堰が魚類相に及ぼす影響, 応用生態工学, 15(2), pp.187-195, 2012

2）岩崎明希人，吉村千洋 : 横断構造物による河川の分断化が 淡水魚の出現確率に及ぼす影響, 土木学会論文集B1（水工 学)，68(4)，pp. I_685- I_690， 2012

3) 財団法人ダム水源地環境整備センター編 : 魚道の設計, 山 海堂, pp5-65, 1991

4) 下田和孝, 中野 繁, 小野有五 : プールタイプ魚道の設置 が北海道の通し回遊魚の流程分布に与える効果, 魚類学雑 誌，50(1)，pp.15-23， 2003

5）国土交通省河川局 : 魚がのぼりや寸い川づくりの手引き， pp.54-55, 2005

6) 農林水産省農村振興局整備部設計課監修：「頭首工の魚 道」設計指針, 公益社団法人農業農村工学会, pp.24-25, 2015

7) Lonnebjerg,N. : Fishway in Denmark, Proceedings of the International Symposium on Fishways '90in Gifu, pp.253-259, 1990

8）安田陽一, 大津岩夫, 浜野龍夫, 三矢泰彦 : 多様な水生生 物の遡上・降河可能な魚道の提案, 河川技術論文集, 7 , pp.221-226, 2001

9) 小出水規行 : 長良川河口堰魚道の遡上魚類群集に関するモ ニタリングデータの解析，河川技術論文集， 8, pp.331-336, 2002

10) Blaxter, J.H.S : Swimming Speeds of Fish, Procedings of the FAO Conference on Fish Behaviour in relation to Fishing Techniques and Tactics, in Bergen,Norway, pp.69-100, 1967

11) 塚本勝巳, 梶原 武: 魚類の遊泳速度と遊泳能力, 水産土 木, 10(1), pp.31-36, 1973

12) 梨本勝昭 : 魚の尾の動きと遊泳速度との関係, 日本水産学 会誌，46(3), pp.307-312, 1980

13) 泉 完, 矢田谷健一, 東 信行, 工藤 明: 河川流下水を 用いたスタミナトンネルによるウグイの突進速度について, 農業土木学会論文集，244，pp.171-178，2006

14) 泉 完, 矢田谷健一, 東 信行, 工藤 明, 加藤 幸 : 自
然河川流下水を用いたスタミナトンネルによるオイカワの 突進速度に関する現地実験, 水工学論文集, 51, pp.12851290, 2007

15) 鬼束幸樹, 秋山壽一郎, 山本晃義, 飯國洋平 : 流速および 体長別のオイカワの突進速度，水工学論文集，52， pp.1183-1188, 2008

16) 鬼束幸樹, 秋山壽一郎, 山本晃義, 渡邊拓也, 脇 健樹 : 河川に生息する数魚種の突進速度に関する研究〜アユ, オ イカワ, カワムツ, ギンブナを対象〜，土木学会論文集B, 65(4), pp.296-307, 2009

17) 泉 完, 大田敏貴, 東 信行 : 河川水を用いた遊泳実験に よるシロウオの遊泳能力と尾部の動き，農業農村工学会論 文集，283，pp.41-50，2013

18) 桜井 力, 柏井条介, 佐々木國隆, 岡嵪克美, 進藤邦雄, 岡本俊策 : コンクリートブロックを用いた粗石式魚道の水 理および遡上特性，水工学論文集，44，pp,1197-1202， 2000

19) 宮園正敏，戸松修 : 斜路式魚道における粗石の配置につい て, 砂防学会誌, 56(1), pp.3-12, 2003

20) 本田隆秀, 浅利修一, 秋野淳一, 高澤浩二, 高島清光, 小 林 博 : 粗石付護床工ブロックの魚道工への適用と治水機 能に関する一考察，土木学会論文集G（環境），168(7), pp.III_227-III_237, 2012

21) 東 信行, 亀井陽太郎, 齋藤 裕, 泉 完: 岩木川におけ る未記録魚種の採捕記録，青森自然誌研究，10, pp.71-72, 2005

22) 道津喜衛 : ウキゴリの生活史, 九大農学芸雑誌, 15(3), pp.367-374, 1955

23) 久保田哲也, 中西 章, 谷口政由貴 : 砂防施設の斜路式魚 道における渓流魚の遡上水理条件, 砂防学会誌, 53(2), pp.48-56, 2000

24) 泉 完, 㐘池真弘, 加藤 幸, 東 信行 : 河川水を用いた ヤマメ稚魚の尾部の動きと遊泳速度, 農業農村工学会論文 集, 278, pp.99-107, 2012

25) 泉 完, 高屋大介, 工藤 明, 東 信行 : アイスハーバー 型魚道における魚類の隔壁遡上特性，農業土木学会論文集， 217, pp.55-63, 2002

26) 泉 完, 菅原賢治, 工藤 明, 東 信行 : バーチカルス ロット型魚道におけるアメマスの現地放流実験, 農業土木 学会誌, 72(7), pp.45-50, 2004

27) 泉 完, 神山公平, 藤原正幸 : 全面越流型階段式魚道プー ル内の流況と魚の遊泳行動, 農業農村工学会論文集, 269 , pp.127-135, 2010

(2015. 9. 30受付) 